\title{
Managing intrathecal administration of nusinersen in adolescents and adults with $5 q$-spinal muscular atrophy and previous spinal surgery
}

\author{
Manejo da administração intratecal de nusinersena em adolescentes e adultos com \\ atrofia muscular espinhal $5 q$ e cirurgia prévia de coluna \\ Rodrigo de Holanda MENDONÇA1', Hermann dos Santos FERNANDES², Rafael Barbéro Schimmelpfeng PINTO³, \\ Ciro MATSUI JÚNIOR', Graziela Jorge POLIDO', André Macedo Serafim da SILVA', Luis Fernando GROSSKLAUSS ${ }^{4}$, \\ Umbertina Conti REED ${ }^{1}$, Edmar ZANOTELI ${ }^{1}$
}

\begin{abstract}
Background: Spinal muscular atrophy (SMA) is a neurodegenerative disease of lower motor neurons associated with frequent occurrence of spinal deformity. Nusinersen is an antisense oligonucleotide that increases SMN protein level and is administrated by frequent intrathecal lumbar injections. Thus, spinal deformities and previous spinal surgery are important challenges for drug delivery in SMA. Objective: To report imaging methods used for Nusinersen injection in SMA patients. Methods: Nusinersen injection procedures in SMA types 2 and 3 patients who had previous spinal surgery were analyzed retrospectively to describe the imaging and puncture procedures, as well as the occurrence of complications. Results: Nine SMA patients (14 to 50 years old) underwent 57 lumbar punctures for nusinersen injection. Six patients had no interlaminar space available; in five of them, a transforaminal approach was used, and another one underwent a surgery to open a posterior bone window for the injections. Transforaminal puncture was performed using CT scan in three cases and fluoroscopy in the other two, with a similar success rate. One patient in the transforaminal group had post-procedure radiculitis, and another one had vagal reaction (hypotension). In three cases, with preserved interlaminar space, injections were performed by posterior interlaminar puncture, and only one adverse event was reported (post-puncture headache). Conclusion: In SMA patients with previous spinal surgery, the use of imagingguided intervention is necessary for administering intrathecal nusinersen. Transforaminal technique is indicated in patients for whom the interlaminar space is not available, and injections should always be guided by either CT or fluoroscopy.
\end{abstract}

Keywords: Muscular Atrophy, Spinal; Antisense Oligonucleotide; Spinal Puncture; Survival of Motor Neuron 1 Protein; Motor Neuron Disease.

\section{RESUMO}

Introdução: A atrofia muscular espinal (AME) é uma desordem neurodegenerativa dos motoneurônios inferiores frequentemente associada à ocorrência de deformidade da coluna vertebral. Nusinersena é um oligonucleotídeo antisense que aumenta os níveis da proteína SMN, sendo administrado através de injeções lombares intratecais frequentes. Assim, deformidades da coluna vertebral e abordagem cirúrgica prévia são desafios importantes para a administração de medicamentos na AME. Objetivo: descrever os métodos de imagens utilizados para administração do Nusinersena nos pacientes com AME. Métodos: Os procedimentos de administração de nusinersena em pacientes com AME dos tipos 2 e 3 submetidos à cirurgia prévia da coluna foram analisados retrospectivamente para descrever os métodos de imagem e punção, e a ocorrência de complicações. Resultados: Nove pacientes com AME (14 a 50 anos) foram submetidos a 57 punções lombares para administração de nusinersena. Seis pacientes tinham enxerto ósseo ou nenhum espaço interlaminar disponível; em cinco deles foi utilizada uma abordagem transforaminal, e outra paciente foi submetida à abertura cirúrgica de janela óssea para as injeções. A punção transforaminal foi realizada usando tomografia computadorizada (TC) em três casos e fluoroscopia nos outros dois, com taxa de

\footnotetext{
1Universidade de São Paulo, Faculdade de Medicina, Departamento de Neurologia, São Paulo SP, Brazil.

Universidade de São Paulo, Faculdade de Medicina, Departamento de Anestesiologia, São Paulo SP, Brazil.

${ }^{3}$ Fleury Medicina Saúde, Radiologia Intervencionista, São Paulo SP, Brazil.

${ }^{4}$ Universidade Federal de São Paulo, Departamento de Neurologia, Divisão Neuromusculares, São Paulo SP, Brazil.

Rodrigo de Holanda MENDONÇA (D) https://orcid.org/0000-0001-7520-3353; Hermann dos Santos FERNANDES (D) https://orcid.org/0000-0001-9298-6118; Rafael Barbéro Schimmelpfeng PINTO (iD https://orcid.org/0000-0001-8203-5685; Ciro MATSUI JÚNIOR (iD https://orcid.org/0000-0002-7304-0279; Graziela Jorge POLIDO (D) https://orcid.org/0000-0002-8748-8509; André Macedo Serafim da SILVA (iD https://orcid.org/0000-0002-5792-5878; Luis Fernando GROSSKLAUSS (ID https://orcid.org/0000-0002-7531-6857; Umbertina Conti REED (D) https://orcid.org/0000-0001-7014-0349;

Edmar ZANOTELI (D) https://orcid.org/0000-0002-4991-6760

Correspondence: Rodrigo de Holanda Mendonça; E-mail: rodrigo.holanda@hc.fm.usp.br.

Conflict of interest: RHM and EZ have received financial compensation from Biogen for congress participation and for talks.

Authors' contribution: RHM and HSF: conceptualized the paper, collected data, analyzed data and wrote the initial draft. RBSP, CMJ, GJP, AMSS, LFG and UCR: collected data and reviewed the manuscript for important intellectual content. EZ: conceptualized the paper, wrote and reviewed the manuscript for intellectual content, supervised the study.

Received on May 7, 2020; Received in its final form on June 10, 2020; Accepted on July 5, 2020.
} 
sucesso semelhante. Um paciente no grupo de abordagem transforaminal apresentou radiculite pós-procedimento e outro apresentou reação vagal (hipotensão). Em três casos, com espaço interlaminar preservado, foram realizadas técnica de punção interlaminar posterior e apenas um evento adverso foi relatado (cefaleia pós-punção). Conclusão: Em pacientes com AME e cirurgia prévia, o uso de intervenção guiada por imagem é necessário para a administração de nusinersena. A técnica transforaminal é indicada nos casos onde o espaço interlaminar não está disponível, devendo ser guiada por TC ou técnicas de imagem fluoroscópica.

Palavras-chave: Atrofia Muscular Espinal; Oligonucleotídeo Antisenso; Punção Espinhal; Proteína 1 de Sobrevivência do Neurônio Motor; Doença dos Neurônios Motores.

\section{INTRODUCTION}

Spinal muscular atrophy (SMA) is a neurodegenerative disease of lower motor neurons from spinal cord and motor nuclei of brainstem, leading to axial and proximal limb weakness associated with ventilatory insufficiency and spinal deformity. The most common form of SMA is caused by deletions or disease-causing variants in the survival motor neuron 1 (SMN1) gene, which segregates as an autosomal recessive trait ${ }^{1}$.

SMA has been classified into at least three subtypes depending on age of disease onset and the achievement of motor milestones'2. Type 1 SMA (severe form, or WerdnigHoffman disease) is characterized by an age of onset of 0-6 months old, and the children are unable to sit unaided. In type 2 SMA (intermediate form), the clinical manifestations start between 6 and 18 months of age, and children are unable to stand or walk unaided. Children with type 3 SMA (mild form) manifest the disease in the second year of life or later and are able to stand or walk unaided ${ }^{2}$.

The SMN2 gene, a centromeric copy of the SMN1 gene, produces a truncated, highly unstable, and non-functional variant of the SMN protein due to a pre-mRNA that undergoes an alternative splicing of exon $7^{3}$. Several studies have demonstrated a strong inverse correlation between the number of SMN2 copies and SMA severity ${ }^{1,4}$. Nusinersen is an antisense oligonucleotide that targets the pre-RNA of SMN2 and increases full-length SMN protein levels. Its effectiveness has been demonstrated in two pivotal trials: one for patients with SMA type 1 and the other for SMA types 2 and $3^{5,6}$. The US Food and Drug Administration (FDA) first approved nusinersen for the treatment of SMA in 2016. The Brazilian National Health Surveillance Agency (ANVISA) approved it in 2017 . Because of its inability to cross the blood-brain barrier, nusinersen is administered intrathecally in a therapeutic regimen requiring four lumbar punctures within two months and consecutive maintenance injections every four months thereafter ${ }^{5,6,7,8,9}$. This administration schedule has proven to be a challenge in patients with scoliosis and in those with previous spinal fusion.

Scoliosis is a frequent manifestation in all forms of SMA, being secondary to progressive weakness of the axial muscles $^{10,11}$. Surgical treatment is indicated in most cases, especially when the curve is greater than 45 degrees, to control curve progression and pelvic obliquity ${ }^{12,13}$. The surgical approach, often with the use of bone graft, makes the conventional lumbar puncture by posterior interlaminar approach a challenge in these patients. The benefit of using imaging to perform lumbar puncture for nusinersen administration in this special population has been well demonstrated ${ }^{14}$. In addition, many innovative reports have addressed the use of different methods for intrathecal nusinersen infusion in SMA patients with scoliosis or with previous spinal surgery ${ }^{15,16,17,18,19,20,21}$.

The aim of this study was to evaluate the feasibility of fluoroscopy and CT imaging, as well as the main technical and safety differences when comparing the transforaminal and posterior interlaminar punctures in the intrathecal administration of nusinersen in patients with SMA and previous spinal surgery.

\section{METHODS}

From March 2018 to December 2019, we retrospectively analyzed the nusinersen injection procedures in SMA types 2 and 3 patients who had a previous extensive posterior thoraco-lumbar spinal fusion. A multidisciplinary team composed of a neurologist and physiotherapist routinely followed up with patients. First, all patients underwent a computed tomography (CT) scan before intrathecal administration. Then, patients were seen by a radiologist with expertise in CT-guided interventions or by an anesthesiologist with expertise in interventional procedures for pain management (procedures guided by fluoroscopy) to choose the best approach. Patients with preserved interlaminar space (Figure 1A) underwent a conventional posterior interlaminar puncture,

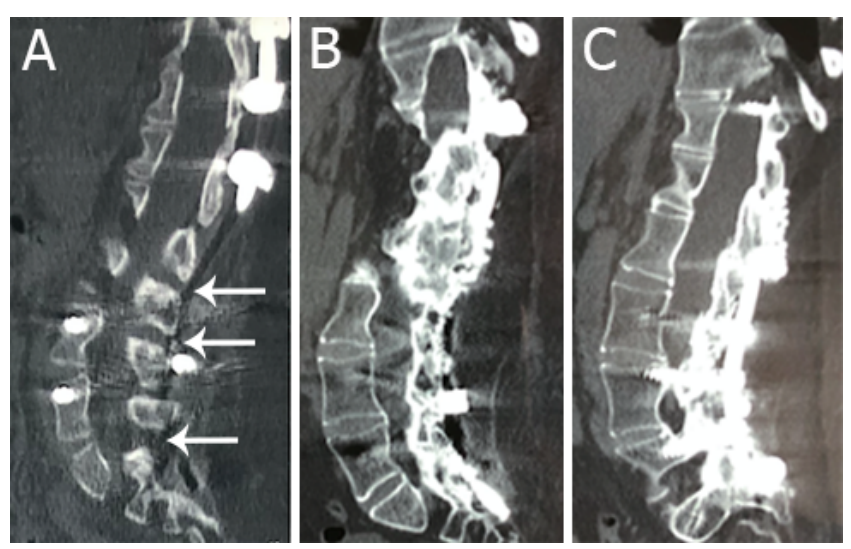

Figure 1. Prior spine computed tomography scan of two different patients. In A, preserved interlaminar space is shown (arrows). In B and C, note the extensive bone graft and no residual interlaminar space. 
whereas those without preserved posterior space (Figures 1B and $1 \mathrm{C}$ ) underwent a transforaminal puncture. Either CT or fluoroscopy was chosen for the procedure depending on the availability of the service and the professional experience of the imaging-guided intervention used.

Technical success was defined by a return of cerebrospinal fluid (CSF) without need of aspiration and complete medication delivery. Adverse events (e.g., post-lumbar puncture syndrome, back pain and radiculopathy) and the need of sedation were recorded.

\section{CT-guided lumbar puncture}

CT-guided access was performed with the patient in lateral decubitus. The procedure was performed in conventional or multislice tomography with local anesthesia. Sedation or general anesthesia is required only in non-collaborative patients, which did not occur in our case series. The procedure duration was approximately 15 minutes and was performed by an interventional radiologist (R.B.S.P.) with tomography-guided intervention expertise.

In transforaminal access, the upper foraminal third ("safety triangle", cranial to the exiting nerve root) is approached using a $22 \mathrm{G}$ spinal needle (Figure 2) to avoid neural or vascular injuries between the L2 to S1 levels.

\section{Fluoroscopy-guided lumbar puncture}

In fluoroscopy-guided lumbar puncture, the patient is positioned in lateral decubitus in a lumbar flexion posture. The fluoroscopy $\mathrm{C}$-arm should be in the anterior-posterior
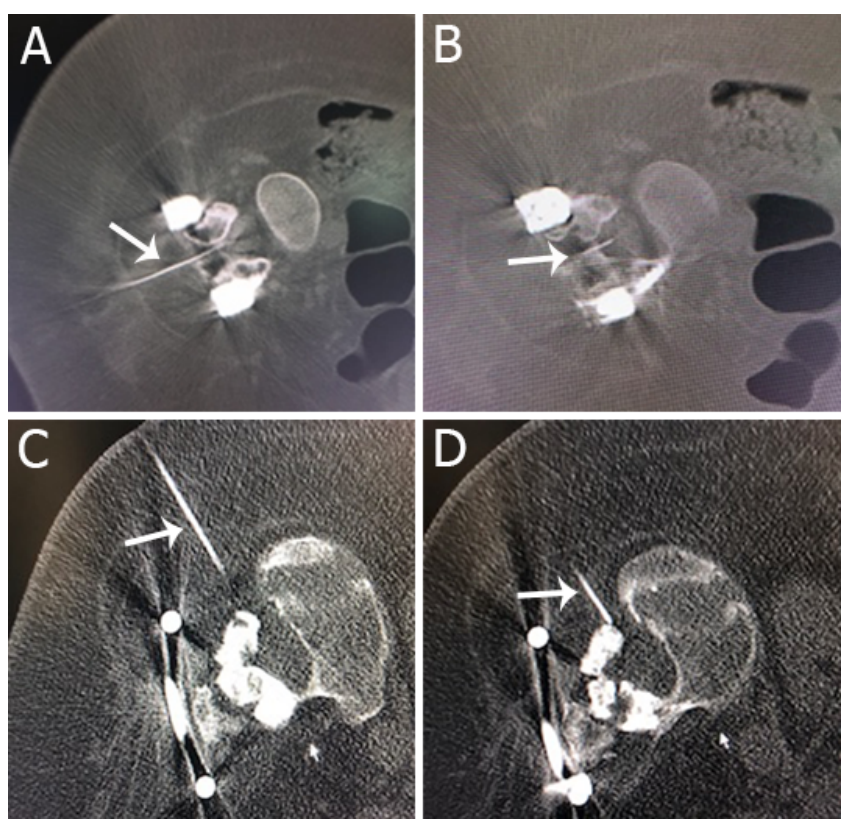

Figure 2. Computed tomography scan for both interlaminar posterior puncture (A and B) and transforaminal lumbar puncture ( $C$ and $D$ ). In $A$, note the needle (arrow) in the posterior aspect of lamina. In B, the needle is located inside the dural sac (arrow). In C, the needle (arrow) and the soft tissues around are visible. $\ln \mathrm{D}$, the needle is located in the posterior aspect of foramen (arrow). position relative to the patient, with slight craniocaudal oblique angulation if necessary.

The entry point between two laminae on the midline was marked and anesthetized. The puncture needle (Quincke 20-22G) was then inserted at the same point and directed parallel to the incidence of fluoroscopy rays, in a technique called "tunnel vision" (the parallel-ray needle is shown as a point) in radioscopy. The needle should be directed $0.5-1.0$ $\mathrm{cm}$ at a time, and its position is checked by radioscopic images and its direction corrected. When loss of resistance is noticed after crossing the yellow ligament and perforating the dura, it is possible to check for CSF reflux. If further confirmation is desired, it is possible to make a fluoroscopic lateral image and check the depth of the needle (Figure 3). Fluoroscopy-guided procedures were performed by a neurologist (R.H.M.) and an anesthesiologist (H.S.F.) with expertise in interventional procedures.

The transforaminal approach is similar to the technique used for transforaminal epidural steroid injection ${ }^{22}$. The $\mathrm{C}$-arm is rotated 30 to 40 degrees lateral oblique to allow direction of the needle toward the superolateral aspect of the intervertebral foramen (Figure 3). The intervertebral foramen is identified, and the surface entry point is marked and anesthetized. Using the "tunnel vision" needling technique, a 20-22G 90-120 mm Quincke needle is advanced, aiming toward the superior third of the foramina (cranial to the exiting nerve root), as shown in Figure 3. After loss of resistance in needle advance, position confirmation with lateral view and fluid reflux is checked, followed by collection of $5 \mathrm{~mL}$ of CSF and medication injection (Figures 3D and 3E).

\section{RESULTS}

Nine SMA patients (six women) underwent 57 lumbar punctures for nusinersen injection (Table 1). The patients'

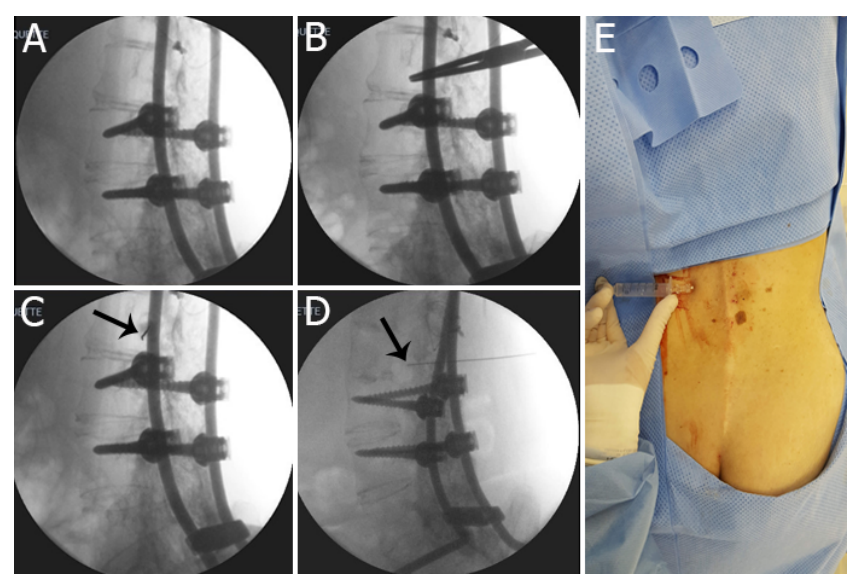

Figure 3. Sequence for transforaminal fluoroscopic-guided spinal injection. (A) Initial image on oblique incidence,

(B) surface mark, (C) tunnel vision needle advance (arrow),

(D) confirmation of needle depth in lateral view, and (E) fluid reflux, as confirmation of spinal puncture. 
ages ranged from 14 to 50 years (mean age $=30.2$ years old) at the first injection. Six patients were diagnosed as having type 2 SMA and three as having type 3 SMA (Table 1), and they were all wheelchair users.

After performing a CT scan, six patients had a CT spine showing bone graft or no interlaminar space available, and in five of them the lumbar puncture was done using a transforaminal approach. One additional patient (patient 1) underwent a surgery to open a posterior bone window before the infusion; the procedure caused longer hospitalization, postoperative pain, need for opioids, and slight functional worsening. In this last case, the following infusions were done by a posterior access guided by fluoroscopy. Transforaminal puncture was performed using CT scan in three cases, and fluoroscopy was used in the two remaining patients, with a $100 \%$ success rate in both approaches.

As shown in Table 1, in three cases, the injection was performed by posterior interlaminar puncture after the CT spine had demonstrated that the interlaminar space was preserved. In these cases, fluoroscopy was the technique most frequently used to guide the punctures. Fluoroscopy and CT scan both showed $100 \%$ success rates.

The rate of adverse events in the 57 procedures was $5.2 \%$ (Table 1), being $6.6 \%$ in the transforaminal approach group $(\mathrm{n}=30)$ and $3.7 \%$ in the posterior interlaminar puncture group $(\mathrm{n}=27)$. In the CT-guided puncture group $(\mathrm{n}=24)$, only one adverse event occurred (4.1\%), whereas in the fluoroscopy-guided puncture group $(\mathrm{n}=33)$, two adverse events $(6 \%)$ were reported. In the transforaminal puncture group, one episode of radiculopathy was reported, with radicular and positional pain, but which reverted in three days after the use of analgesics. Two patients required mild sedation with midazolam due to needle phobia, without further complication.

\section{DISCUSSION}

In this study, we present nine patients with SMA who had previous spine surgery and who underwent repeated lumbar punctures for nusinersen treatment. Fifty-seven procedures were performed with a very low rate of adverse events. In six patients, a CT spine showed bone graft or no interlaminar space available, and in five of them the lumbar puncture was done using a transforaminal approach. Five out of nine patients had fluoroscopic procedures, and similar success and adverse event rates were seen compared to CT-guided punctures.

As previously suggested, a posterior interlaminar puncture is possible when a CT scan detects an available interlaminar space, otherwise a transforaminal approach is indicated ${ }^{15,16,18,20,21}$. Some studies have already shown success with transforaminal puncture in patients with SMA $^{15,16,17,18,19,20,21}$. Using cone-beam CT guidance with twoaxis fluoroscopic navigational overlay, Weaver et al. showed the safety and efficacy of transforaminal intrathecal delivery of nusinersen in four children with $\mathrm{SMA}^{15}$. Geraci et al. described the transforaminal approach for intrathecal nusinersen delivery in five adult SMA patients, for a total of 17 doses, and reported no major complications ${ }^{16}$. Nascene et al. reported no adverse events in a cohort of seven adult SMA patients submitted to a transforaminal approach using CT or fluoroscopy guidance ${ }^{17}$. Bortolani et al. treated twelve teenage and adult SMA patients who had previous spinal surgery or severe spinal deformity with nusinersen ${ }^{19}$. The authors used the transforaminal approach (seven patients) or the interlaminar approach ( five patients) under CT guidance. In 47 injections, the procedure had a $97.8 \%$ success rate, with $5 \%$ of the interlaminar approach group experiencing adverse events and 15\% in the transforaminal group. In the latter group, a patient

Table 1. Spinal muscular atrophy patients with previous spinal surgery who underwent treatment with nusinersen.

\begin{tabular}{|c|c|c|c|c|c|c|c|c|c|}
\hline $\mathrm{Pt}$ & $\begin{array}{l}\text { SMA } \\
\text { type }\end{array}$ & Age/sex & $\begin{array}{l}\text { Age at spinal } \\
\text { fusion }\end{array}$ & $\begin{array}{c}\text { Interlaminar } \\
\text { space available }\end{array}$ & $\begin{array}{l}\text { Imaging } \\
\text { for LP }\end{array}$ & $\begin{array}{l}\text { TFA or PIA/level } \\
\text { of puncture }\end{array}$ & $\begin{array}{l}\text { Total of } \\
\text { LP }\end{array}$ & Sedation & $\mathrm{AE}$ \\
\hline 1 & 2 & 23y, F & $8 y$ & No & $\mathrm{FL}$ & PILP*/ L4-L5 & 8 & Yes, MDZ & $\begin{array}{l}\text { Post-puncture } \\
\text { headache }\end{array}$ \\
\hline 2 & 2 & 50y, M & $20 y$ & Yes & CT & PILP/ L3-L4 & 7 & No & No \\
\hline 3 & 2 & 19y, M & $12 y$ & No & $\mathrm{FL}$ & TFLP/L3-L4 & 7 & Yes, MDZ & No \\
\hline 4 & 3 & 29y, F & $13 y$ & Yes & $\mathrm{FL}$ & PILP/L3-L4 & 6 & No & No \\
\hline 5 & 2 & $14 y, F$ & $10 y$ & Yes & $\mathrm{FL}$ & PILP/L3-L4 & 6 & No & No \\
\hline 6 & 2 & 36y, F & $23 y$ & No & CT & TFLP/L4-L5 & 6 & No & $\begin{array}{c}\text { Vagal reaction } \\
\text { with hypotension }\end{array}$ \\
\hline 7 & 2 & 26y, M & $13 y$ & No & CT & TFLP/ L4-L5 & 6 & No & No \\
\hline 8 & 3 & $37 y, F$ & $18 y$ & No & $\mathrm{FL}$ & TFLP/L3-L4 & 6 & No & Radiculopathy \\
\hline 9 & 3 & 38y, F & $17 y$ & No & CT & TFLP/L3-L4 & 5 & No & No \\
\hline
\end{tabular}

SMA: spinal muscular atrophy; Age: age at first infusion; y: years; F: female; M: male; FL: fluoroscopy; CT: computed tomography; TFLP: transforaminal lumbar puncture; PILP: posterior interlaminar lumbar puncture; MDZ: midazolam; AE: adverse events. *Patient 1 was initially submitted to a spinal surgical opening of a bone window for interlaminar posterior access. 
suffered a serious adverse event, which was a subarachnoid hemorrhage that required hospitalization. The authors considered the transforaminal approach an effective option for nusinersen administration in highly selected patients, but potential serious complications should be considered $^{19}$. More recently, Cordts et al. reported 53 CT-guided lumbar punctures of 11 adult non-ambulatory SMA type 2 and 3 patients with $100 \%$ of success with post-lumbar puncture syndrome occurring in $9.4 \%$ of the punctures ${ }^{21}$. In eight lumbar punctures from four patients with complete osseous fusion, the authors proceeded with alternative routes of nusinersen injections including transforaminal punctures and translaminar drilling ${ }^{21}$. In addition, in patients submitted to the transforaminal approach, the authors reported a high rate of complications; a root irritation syndrome in two patients (one had CSF signs of a subarachnoid hemorrhage) and a severe headache and lumbar back pain in another one ${ }^{21}$. In our study, radiculopathy was also reported in the transforaminal group. We noted a slightly higher rate of adverse events in the transforaminal approach compared to the interlaminar group, but no serious adverse events were reported.

Labianca and Weinstein performed a laminotomy at the L3-L4 level for the intrathecal injection of nusinersen in five SMA patients ${ }^{23}$. The procedure was carried out during the scoliosis surgery, or for those who underwent posterior spinal fusion earlier, a second procedure was necessary to perform the laminotomy. A similar approach was used in one of our patients, in which the interlaminar space was not available for the puncture. However, this procedure is much more complicated, and in our case, we noticed longer hospitalization, postoperative pain, need for opioids, and slight functional worsening. Thus, we advise that the use of a transforaminal approach guided by imaging should be tried first, before the indication of the laminotomy.

Our study showed that transforaminal or posterior interlaminar punctures guided by fluoroscopy or CT imaging is feasible, with similar rates of complication and success, regardless of the imaging method used. The main advantages in fluoroscopy-guided transforaminal spinal puncture are availability of the equipment (fluoroscopic C-arms are more often available than CT scan machines) and lower cost, and the main disadvantage is the low-resolution image, especially for soft tissues ${ }^{22}$. CT-guided intrathecal punctures are a safe and effective option, especially in patients with arthrodesis and scoliosis, with or without posterior bone graft. Its main advantages include a single puncture from a single contact with the dura-mater, which favors lower incidence of post-puncture headache, lower pain during the procedure, greater comfort, and a reduced need for sedation or general anesthesia. This option also allows visualization of the needle bezel inside the dural sac, an aspect that guarantees proper needle positioning even in cases where there is no return of CSF, as well as better visualization of soft tissues ${ }^{17}$. However, none of the mentioned imaging techniques accurately visualizes vascular structures, such as radicular arteries, which can lead to bleeding and even serious adverse events such as subarachnoid hemorrhage after transforaminal puncture ${ }^{19}$.

Average exposure to radiation with CT guidance is comparable to a standard abdominal/pelvic tomographic examination $(9.95 \mathrm{mSV})^{24,25}$. The study's use of targeted CT programming contributes to low doses of absorbed radiation; as in intrathecal punctures, a few tomographic sections are performed (about 30 sections) instead of a complete spinal study (about 500 sections) ${ }^{26}$.

Our study has some limitations, such as the small number of subjects included. In addition, it is a retrospective study carried out in different institutions, in which there was no prior planning and standardization of the applied techniques, and thus, the comparison between them was limited.

In adults and adolescents with SMA and previous spine surgery, the use of imaging-guided intervention is necessary for administering intrathecal nusinersen. The transforaminal technique is a safe procedure indicated in cases where the interlaminar space is not available, and it should always be guided by either $\mathrm{CT}$ or fluoroscopic imaging. Both imagingguided interventions seem equally effective. Although fluoroscopy is more readily available, the CT-guided procedure offers better visualization of bone structures and soft tissues and should be preferred when available.

\section{ACKNOWLEDGEMENT}

We are thankful to the patients and parents who participated in this study.

\section{References}

1. Lefebvre S, Bürglen L, Reboullet S, Clermont O, Burlet P, Viollet $L$, et al. Identification and characterization of a spinal muscular atrophy-determining gene. Cell. 1995 Jan;80(1):155-65. https://doi. org/10.1016/0092-8674(95)90460-3

2. Munsat TL, Davies KE. International SMA consortium meeting. (26-28 June 1992, Bonn, Germany). Neuromuscul Disord. 1992;2(5-6):423-8. https://doi.org/10.1016/s0960-8966(06)80015-5
3. Cartegni L, Krainer AR. Disruption of an SF2/ASF-dependent exonic splicing enhancer in SMN2 causes spinal muscular atrophy in the absence of SMN1. Nat Genet. 2002 Apr;30(4):377-84. https://doi.org/10.1038/ng854

4. Mendonça RH, Matsui C Jr, Polido GJ, Silva AMS, Kulikowski L, Torchio Dias A, et al. Intragenic variants in the SMN1 gene determine the clinical phenotype in 5q spinal muscular atrophy. Neurol Genet. 2020 Sep;6(5):e505. https://doi.org/10.1212/NXG.0000000000000505 
5. Finkel RS, Mercuri E, Darras BT, Connolly AM, Kuntz NL, Kirschner $J$, et al. Nusinersen versus sham control in infantile-onset spinal muscular atrophy. N Engl J Med. 2017 Nov;377(18):1723-32. https:// doi.org/10.1056/NEJMoa1702752

6. Mercuri E, Darras BT, Chiriboga CA, Day JW, Campbell C, Connolly AM, et al. Nusinersen versus sham control in later-onset spinal muscular atrophy. N Engl J Med. 2018 Feb;378(7):625-35. https://doi. org/10.1056/NEJMoa1710504

7. Reed UC, Zanoteli E. Therapeutic advances in 5q-linked spinal muscular atrophy. Arq Neuro-Psiquiatr. 2018 Apr;76(4):265-72. https://doi.org/10.1590/0004-282×20180011

8. Mendonça RH, Polido GJ, Matsui C, Silva AMS, Solla DJF, Reed UC, et al. Real-world data from nusinersen treatment for patients with later-onset spinal muscular atrophy: a single center experience.J Neuromuscul Dis. 2021;8(1):101-8. https://doi.org/10.3233/JND200551

9. Mendonça RH, Polido GJ, Matsui C, Solla DJF, Reed UC, Zanoteli E. Clinical Outcomes in Patients with Spinal Muscular Atrophy Type 1 Treated with Nusinersen. J Neuromuscul Dis. 2021 Jan. [Epub ahead of print]. https://doi.org/10.3233/JND-200533

10. Rodillo E, Marini ML, Heckmatt JZ, Dubowitz V. Scoliosis in spinal muscular atrophy: review of 63 cases. J Child Neurol. 1989 Apr;4(2):118-23. https://doi.org/10.1177/088307388900400208

11. Fujak A, Raab W, Schuh A, Richter S, Forst R, Forst J. Natural course of scoliosis in proximal spinal muscular atrophy type II and IIIa: descriptive clinical study with retrospective data collection of 126 patients. BMC Musculoskelet Disord. 2013 Oct;14:283. https://doi. org/10.1186/1471-2474-14-283

12. Mercuri E, Finkel RS, Muntoni F, Wirth B, Montes J, Main M, et al. Diagnosis and management of spinal muscular atrophy: part 1: recommendations for diagnosis, rehabilitation, orthopedic and nutritional care. Neuromuscul Disord. 2018 Feb;28(2):103-15. https://doi.org/10.1016/j.nmd.2017.11.005

13. Roso V, Bitu S de O, Zanoteli E, Beteta JT, Castro RC, Fernandes AC. Surgical treatment of scoliosis in spinal muscular atrophy. Arq Neuro-Psiquiatr. 2003 Sep;61(3A):631-8. https://doi.org/10.1590/ s0004-282x2003000400020

14. Stolte B, Totzeck A, Kizina K, Bolz S, Pietruck L, Mönninghoff $C$, et al. Feasibility and safety of intrathecal treatment with nusinersen in adult patients with spinal muscular atrophy. Ther Adv Neurol Disord. 2018 Oct;11:1756286418803246. https://doi. org/10.1177/1756286418803246

15. Weaver JJ, Natarajan N, Shaw DWW, Apkon SD, Koo KSH, Shivaram GM, et al. Transforaminal intrathecal delivery of nusinersen using cone-beam computed tomography for children with spinal muscular atrophy and extensive surgical instrumentation: early results of technical success and safety. Pediatr Radiol. 2018 Mar;48(3):392-7. https://doi.org/10.1007/s00247-017-4031-6
16. Geraci AP, Black K, Jin M, Rimler S, Evans A. Transforaminal lumbar puncture for intrathecal nusinersen administration. Muscle Nerve. 2018 Jan. https://doi.org/10.1002/mus.26082

17. Nascene DR, Ozutemiz XC, Estby XH, McKinney AM, Rykken JB. Transforaminal lumbar puncture: an alternative technique in patients with challenging access. AJNR Am J Neuroradiol. 2018 May;39(5):986-91. https://doi.org/10.3174/ajnr.A5596

18. Wurster CD, Winter B, Wollinsky K, Ludolph AC, Uzelac Z, Witzel S, et al. Intrathecal administration of nusinersen in adolescent and adult SMA type 2 and 3 patients. J Neurol. 2019 Jan;266(1):183-94. https://doi.org/10.1007/s00415-018-9124-0

19. Bortolani S, Stura G, Ventilii G, Vercelli L, Rolle E, Ricci F, et al. Intrathecal administration of nusinersen in adult and adolescent patients with spinal muscular atrophy and scoliosis: transforaminal versus conventional approach. Neuromuscul Disord. 2019 Oct;29(10):742-6. https://doi.org/10.1016/j.nmd.2019.08.007

20. Jacobson JP, Cristiano BC, Hoss DR. Simple Fluoroscopy-Guided Transforaminal Lumbar Puncture: Safety and Effectiveness of a Coaxial Curved- Needle Technique in Patients with Spinal Muscular Atrophy and Complex Spines. AJNR Am J Neuroradiol. 2020 Jan;41(1):183-8. https://doi.org/10.3174/ajnr.A6351

21. Cordts I, Lingor P, Friedrich B, Pernpeintner V, Zimmer C, Deschauer $M$, et al. Intrathecal nusinersen administration in adult spinal muscular atrophy patients with complex spinal anatomy. Ther Adv Neurol Disord. 2020 Jan;13:1756286419887616. https://doi. org/10.1177/1756286419887616

22. Stolzenberg D, Ahn JJ, Kurd M. Fluoroscopically guided lumbar transforaminal epidural steroid injection: procedural technique. Clin Spine Surg. 2018 Aug;31(7):297-9. https://doi.org/10.1097/ BSD.0000000000000627

23. Labianca L, Weinstein SL. Scoliosis and spinal muscular atrophy in the new world of medical therapy: providing lumbar access for intrathecal treatment in patients previously treated or undergoing spinal instrumentation and fusion. J Pediatr Orthop B. 2019 Jul;28(4):393-6. https://doi.org/10.1097/BPB.0000000000000632

24. Dietrich TJ, Peterson CK, Zeimpekis KG, Bensler S, Sutter R, Pfirrmann CWA. Fluoroscopy-guided versus CT-guided lumbar steroid injections: comparison of radiation exposure and outcomes. Radiology. 2019 Mar;290(3):752-9. https://doi.org/10.1148/radiol.2018181224

25. Kizina K, Stolte B, Totzeck A, Bolz S, Fleischer M, Mönninghoff C, et al. Clinical implication of dosimetry of computed tomographyand fluoroscopy-guided intrathecal therapy with nusinersen in adult patients with spinal muscular atrophy. Front Neurol. 2019 Nov;10:1166. https://doi.org/10.3389/fneur.2019.01166

26. Oldenburg D, Guberina N, Stolte B, Kizina K, Stenzel E, Radbruch A, et al. Radiation exposure of image-guided intrathecal administration of nusinersen to adult patients with spinal muscular atrophy. Neuroradiology. 2019 May;61(5):565-74. https://doi.org/10.1007/s00234-019-02189-x 